\title{
Development of the Laws of Tortious Liability in Bangladesh
}

\section{Naima Haider \\ Judge, High Court Division, Supreme Court of Bangladesh}

Throughout advanced legal systems, tort law is a very popular and an advanced area of practice. Unfortunately, this is not the case with the legal system of Bangladesh. Generally speaking, which is the worst of all, there is a misconception that there is no tort law in Bangladesh. There is no doubt that this misconception is fundamentally based on the fact that we do not have any statute respecting tort law. However, we have some statutes in our country that tacitly address various issues of tort law both in our criminal and civil jurisprudence. On top of that both of our Appellate Division and the High Court Division of the Supreme Court have given some substantially important judgments that have directly developed the laws of tortious liability within our jurisdiction. In this article, some of those very important judgments of our Supreme Court would be discussed with specific reference as to how those judgments are having an impact in developing the tortious regime within the legal system of Bangladesh.

Bangladesh Beverage Industries Limited $v$ Rawshan Aktar and Ors ${ }^{1}$ is a seminal case in the context of assessment of damages in tortious claims. Moreover, in this case the apex court of Bangladesh has laid down significantly important principles which would substantially assist the plaintiff to identify the heads of damages and also to calculate the quantum of damages when the plaintiff is seeking relief from the court of law under the cause of action of negligence. Here the suit in question was originally filed in the form of a Money Suit by the wife and two minor sons of the deceased as plaintiffs whereby the deceased who was a news reporter of "The Daily Songbad" died of a fatal accident caused by a mini truck hitting him from the wrong side while he was crossing the road. The trial court in decreeing the suit in favor of the plaintiffs awarding damages amounting to $\mathrm{Tk} 3,52,97,000 /$ - found that the driver of the defendant was driving the vehicle negligently, recklessly and in violation of law. Before embarking on the aspect of quantum of damages, it is noteworthy to mention that admittedly the cause of action in that case was negligence, the root of which obviously lies in tort law.

This case subsequently went up to the High Court Division whereby the High Court Division allowed the appeal-in-part and modified the judgment and decree, and finally to the Appellate Division whereby the Appellate Division disposed of the leave petition with some observations upholding entitlement of the plaintiffs in the suit to get a decree of Tk 1,71,47,008/-.Therefore, it is manifestly clear from the judgment of the apex court that in upholding the decree, though in a modified form, the highest court of our country recognized the tort of negligence within the jurisdiction of Bangladesh. Following Article 111 of the Constitution of the People's Republic of Bangladesh, the implication of this judgment is enormous because all the courts subordinate to the Appellate Division which includes the High Court Division are bound by the law

1 Bangladesh Beverage Industries Limited v Rawshan Aktar and Ors (2016) 4 CLR (AD) 411. 
declared by the Appellate Division.

Now, two things certainly follow this judgment. Firstly, the tortious cause of action of negligence has its root at common law or case law in Bangladesh as this is the same in both the United Kingdom and India. Secondly, the claim under the cause of action of negligence would have to be brought by the plaintiffs in the form of a money suit. Dealing with the first aspect requires some consideration of some settled laws in most of the advanced jurisdiction like that of the UK and United States of America. As the UK has a common law jurisdiction and as our legal system still has a lot of laws that we have retained since the British period including the Code of Civil Procedure 1908, it is worthwhile to briefly look into the development of the law of negligence in the UK.

Donoghue $v$ Stevenson ${ }^{2}$ is certainly the starting point in this regard which is the most classical English case on the point of tort law and the law of negligence. The UK House of Lords in that case developed the famous doctrine of neighbor principle. Determination of the success of the plaintiff's claim for negligence would depend on the proof of certain elements, i.e. the duty of care, breach of that duty of care, causation and remoteness of damages. Over the time, different cases have laid down different tests for proving each of these elements. When professionals were sued for breach of their professional duty, the courts have laid down special tests for professionals. After many academic debates and changes of some common laws, it can now safely be assumed that the above-mentioned elements of the law of negligence are now universally accepted. The Indian jurisdiction has also adopted a similar approach towards the law of negligence.

In Bangladesh Beverage Industries Limited, after assessment of evidence, the trial court found that the driver of the defendant was recklessly driving the mini truck in the course of his employment causing serious injury to the victim which led to his death in the hospital; and also, that the driver of the defendant was driving the vehicle negligently, recklessly and in violation of law. Analysis of these two findings is vitally important to understand the nature of development of tort law in Bangladesh through case laws. While finding the defendant liable for the tort committed by its driver in the course of his employment, the trial court and both the Divisions of the Supreme Court of Bangladesh applied the doctrine of vicarious liability. Learned advocate of the petitioner argued that the trial court erred in law in failing to find out whether the employee was acting within the course of his employment before the employer can be held vicariously liable for his employee's tort. Even though the Appellate Division held that the High Court Division rightly found that the petitioner was vicariously liable for the fault of the driver, this aspect of vicarious liability was not discussed in the judgment. This is why it is pertinent to investigate into how the doctrine of vicarious liability is getting developed in our jurisprudence and also what the legal requirement of the doctrine is when proof of the same will be in issue.

It should be noted that vicarious liability, being a tortious concept, is not a cause of

2 Donoghue v Stevenson (1932) UKHL 100. 
action. Vicarious liability is in essence a form of joint liability whereby the employer can be sued for the tort committed by its employees in course of his employment. Therefore, application of the doctrine of vicarious liability allows the plaintiff to hold liable the employer for the action or omission of his employee even though the employer was not directly involved in the said commission or omission. In determining the issue as to who is an employee, classically the level of control over the supposed employee by the employer is to be looked into. ${ }^{3}$ Whether or not the employer has sufficient control over his employee is certainly a matter of fact and it requires taking of evidence from the contesting parties. An interesting case on this point is Grameenphone Ltd. v Chairman, First Labour Court, Dhaka and Ors ${ }^{4}$ even though this case was decided in our writ jurisdiction and in the same the judgment of the Labour Appellate Tribunal was in issue.

Throughout the world, outsourcing of workers from third parties to the supposed employers is a burning issue. If we turn to the UK law, Viasystems (Tyneside) Ltd v Thermal Transfer (Northern) Ltd $d^{5}$ marks a radical change in the English tort law approach whereby for the first time the concept of dual vicarious liability was established. Prior to Viasystems, it was understood that the doctrine of vicarious liability applies to only one employer and it was one of the fundamental tasks of the court to identify who the potential employer is where more than one employer was in the scene. Clearly the decision in Viasystems is a dynamic judgment evidently showing the ability of common law to respond to changing social conditions. ${ }^{6}$ The judgment of the above cited Grameenphone Ltd case in our jurisdiction is, in my opinion, somehow laying down a somewhat different principle to that of Viasystems.

In Grameenphone Ltd, even though the respondent workers had been working and providing services for the petitioner Grameenphone Ltd company, their Lordships concluded that there was no contract of employment or service between the respondent worker and the petitioner Company Grameenphone. Their Lordships further concluded that the respondent workers are merely outsourced workers/drivers employed by the respondent No. 4 (Smart Services Ltd. and/or Jamsons International) on the terms and conditions agreed between the petitioners and the respondents No. 4. Thus since the respondent workers are not even employees of the petitioner Grameenphone the question of treating them 'permanent workers' of the petitioner does not arise. ${ }^{7}$ Therefore, so far as outsourcing of employees is concerned, the Grameenphone $L t d$ case would stand as a strong proposition in favor of the employers against who the plaintiffs might bring a tortious claim under the doctrine of vicarious liability.

Another very interesting case of our jurisdiction on the point of vicarious liability is

Fleming James Jr, 'Vicarious Liability' (1953-1954) 28 Tul L Rev 161, 173.

Grameenphone Ltd. $v$ Chairman, First Labour Court, Dhaka and Ors (2018) 70 DLR 581.

Viasystems (Tyneside) Ltd v Thermal Transfer (Northern) Ltd (2005) England \& Wales Court of Appeal, Civil Division (EWCA Civ) 1151 (2006) Queen's Bench (QB) 510.

6 Paula Giliker, 'Vicarious Liability on the Move: The English Supreme Court and Enterprise Liability' (2013) 4 JETL 306, 307.

7 Grameen Phone Ltd (n 4) para 33.

Page $\mid 198$ 
British American Tobacco Bangladesh Company Ltd v Begum Shamsun Nahar ${ }^{8}$ where a female employee of the appellant company filed a money suit against the employer company claiming damages for the tort committed by its employees at her workplace by committing acts of sexual harassment and bullying on her even when she had been persistently bringing the same to the notice of her superior officer. The employer company filed an application for rejection of plaint in the trial court which was rejected and then the employer company filed a civil revision in which the High Court finally discharged the Rule. Subsequently the employer company moved a civil petition for leave to appeal before the Appellate Division.

The Appellate Division in the British American Tobacco case held that "A person can be liable for tort as well and damages may be claimed against him for such wrong doing as well as against an organization or establishment if it fails to ensure the prevention of sexual harassment and bullying to a woman, where she can work with honour and dignity and without being harassed or disturbed by her male boss or other male colleagues." "The Appellate Division further observed that "...Whatever may be the allegations made by the plaintiff in the plaint, whether the employees of the defendantcompany harassed her in the work place, or the plaintiff made written complaints to the management of the defendant-petitioner-company about the sexual harassment and bullying by the said employees of the defendant-petitioner-company and whether the defendant-petitioner-company took any step to remedy the grievances of the plaintiffrespondent, or the defendant-petitioner-company took steps to prevent or deter the commission of the acts of sexual harassment and bullying by its employees and whether the defendant-petitioner-company could be held responsible for such sexual harassment and bullying caused to the plaintiff-respondent are all questions of facts and can only be decided on the evidence to be adduced by the concerned parties in the trial of the case. Moreover, question of vicarious liability of the defendant-petitionercompany is also a question of fact to be proved by adducing evidence. Both the High Court Division and the Trial Court from clear reading of the plaint rightly found that the plaintiff has clearly stated the facts of the cause of action to bring the suit against the defendant. The power to reject a plaint should not be exercised hastily without affording opportunity to the plaintiff to cure the defect or to amend the plaint." 10

From the above discussions, it is clear that the settled law of our jurisdiction is that vicarious liability is a matter of fact, and not that of law. Determination of the issue as to whether or not the employee has committed a tort in course of his employment is, thus, clearly a matter of fact which can only be ascertained after all the contesting parties have adduced evidence before the trial court. However, it remains arguable as to what would amount to a course of employment and to what extent the court would extend the doctrine of vicarious liability, e.g. when the employee is working for his own purpose and not for the purpose of facilitating his employer's business. Noteworthy to mention in this regard that the meaning of "course of employment" has

8 British American Tobacco Bangladesh Company Ltd v Begum Shamsun Nahar (2014) 66 DLR (AD) 80.

9 Ibid, para 12.

10 Ibid. 
been very debatable in the recent years in many jurisdictions. However, in light of the British American Tobacco case, it can safely be said, at least for the time being, that whether or not the employee has committed the tort in course of his employment is a matter of fact the ascertainment of which would certainly require adducing of evidence before the trial court.

It is also very interesting to note that the criminal jurisprudence of our country also recognizes the concept of vicarious liability. The relevant section in this regard is section 34 of the Penal Code 1860 which reads as follows: "When a criminal Act is done by several persons in furtherance of common intention of all each of such person is liable for that Act in the same manner as if it were done by him alone." Section 34 of Penal Code thus recognizes the principle of vicarious liability in criminal jurisprudence. ${ }^{11}$ It makes a person liable for action of an offence not committed by him but by another person with whom he shared the common intention. It is a rule of evidence and does not create a substantive offence. ${ }^{12}$ As vicarious liability does not and cannot operate as a cause of action in the context of civil law, it cannot operate as an offence in the criminal law context. Proof of the doctrine of vicarious liability is completely dependent on the evidence adduced by the parties in a case and this is applicable in the context of both civil and criminal law. Therefore, it can very strongly be argued that vicarious liability is an established concept in our jurisprudence and judicial recognition of the same by the apex court of our country certainly means that substantial development of tort law in the Bangladeshi legal system is only just a matter of time.

Now returning to the second substantial finding of the trial court in the Bangladesh Beverage Industries Limited case to the effect that the driver of the defendant was driving the vehicle negligently, recklessly and in violation of law, a very interesting point comes to the forefront. From this finding this is clear that the trial court decreed the suit on recognition of the cause of action of negligence which undoubtedly has its root under tort law. Later, the High Court Division and the Appellate Division have also recognized this cause of action of negligence under tort law. Both the Divisions of the Supreme Court heavily emphasized on various tortious measures while assessing the heads of damages and determining the quantum of the same. However, before embarking on the aspect of damages of tortious nature, it is pertinent to understand how the tort of negligence and other torts are getting recognition within our legal framework.

Our High Court Division in a case while recognizing the tort of nuisance has stated that respecting tort law claims, we do not have any statute of our own. ${ }^{13}$ Therefore, our courts have always adopted the English common law as being consonant to justice, equity and good conscience. ${ }^{14}$ I wholeheartedly agree with this view as tort is a subject

\footnotetext{
Aminul Islam and others $v$ The State (2007) 12 BLC 332, para 16.

Ibid.

Wahid Mia alias Abdul Wahid Bhuiyan v Dr. Rafiqul Islam and others (1997) 49 DLR 302, para 9.

14 Ibid.
}

Page $\mid 200$ 
mostly based on common law under the UK legal system. Even though popular tortious causes of action like occupiers' liability, product liability and defamation have started to get statutory framework in the English legal system, the most important cause of action of negligence still has its basis in common law in the UK. As already seen, the law of tort is developing in Bangladesh in the form of case laws of both the Divisions of the Supreme Court. The two judgments of the Appellate Division already cited above contain very specific reference in this regard which would further advance our understanding in this area.

In the Bangladesh Beverage Industries Limited case, the Appellate Division specifically approved the observation of the High Court Division whereby the High Court Division opined that the judges are empowered to create new tort and also that the pain, agony, anguish, suffering and loss of expectation of life are tortious liability for which monetary compensation can be awarded. ${ }^{15}$ While maintaining that tort is a common law action, the Appellate Division in the British American Tobacco case gave the following findings:

"9. The original definition of tort that appeared in the well-known work on Law of Torts by Clerk and Lindsell ran as follows: 'A tort may be described as a wrong independent of contract, for which the appropriate remedy is a common law action.' Underhill amplifies this definition thus:

A tort is an act or omission which is not authorized by law, and independently of contract infringes either-

(a) some absolute right of another;

(b) some qualified right of another causing damage; or

(c) some public right resulting in some substantial and particular damage to some person beyond that which is suffered by the public generally;

and gives rise to an action for damages at the suit of the injured party."16

Therefore, a thorough perusal of the said two judgments of the apex court makes it clear that the law of tort has its basis at common law and, thus, the same would have to be developed through case laws. No doubt that it requires judicial activism on the part of the judges and the recent attitude of the judiciary towards such development obviously requires close scrutiny to deeply understand the judicial approach towards tort law in Bangladesh. Even after the two judgments of the Appellate Division cited above have been reported in well reputed law journals of the country, recognition of the law of tort by the courts below has been almost insignificant. The British American Tobacco case has been reported in 2014 and the Bangladesh Beverage Industries Limited case has been reported in 2016. Even after the lapse of a substantial period since then, the number of reported case laws in the areas of tort law is almost nonexistent, except for some very few. In the meantime, compensation culture is somehow

15 Bangladesh Beverage Industries Ltd (n 1) para 27.

16 British American Tobacco Bangladesh Company Ltd (n 8) para 9. 
getting developed within our writ jurisdiction but, in my opinion, the law of tort would have to be developed within the civil jurisdiction of our legal system as this is the case with all the advanced legal systems including India.

The concern as to the lack of development of tort law was made manifestly clear by the High Court Division in the case of Catherine Masud and others v Md Kashed Miah and others. ${ }^{17}$ In the Catherine Masud case, the High Court Division firstly disposed of some transfer petition cases under Article 110 of the Constitution of the People's Republic of Bangladesh. In this case, the High Court Division made the following observations:

"15. We also note that the petitioner's claim raises questions as to application of the law of tort in Bangladesh. As part of the English Common law, the law of tort has become part of the law in India, as it is not considered contrary to "justice, equity, and good conscience" (Law of Torts by Dr. Nurun Nahar, published by Bangladesh Law Book Co. 1st Edition, 2011). It has also become part of the law in many other Commonwealth countries. However, law of tort is not integral part of the legal structure of Bangladesh. This is primarily because the subordinate courts do not feel empowered to determine a tortious claim unless the tortious claim is purely statutory. For that reason, we do not see rulings of the subordinate courts on medical negligence, vicarious liability etc. We were unable to provide guidelines since we were not called upon to review the issues relating to tort in entirety. In our opinion, the time has come for us to review the law of tort and consider whether law of tort should be incorporated in Bangladesh law so that claims arising from negligence, be it medical or otherwise, are properly dealt with." 18

Two very important points emerge from the above observations of the High Court Division. First of all, in both the Wahid Mia case ${ }^{19}$ (cited above) and Catherine Masud case, the High Court Division emphasized on the concept of "justice, equity and good conscience" for recognizing and developing the law of tort in Bangladesh. Secondly, in the Catherine Masud case, the High Court Division expressed its concern explicitly about the lack of rulings of the subordinate courts on matters of tort law as because the High Court Division felt that the subordinate courts do not feel empowered to determine a tortious claim. Earlier it was noted that Appellate Division expressed that the judges are empowered to create new tort. Now the question arises as to the validity of the concern of the High Court Division about the lack of rulings from the subordinate courts in tort law cases even when the Appellate Division has expressly approved the judicial empowerment in creating new tort.

Even though this question does have an academic dimension, the answer to it lies in the practical arena. If we consider various news getting huge coverage in national media as well as social media, we would find a substantial number of cases involving allegations of clinical negligence, rash and reckless driving, fire at work places etc., all of which are matters of tortious nature. However, in practice, very few cases are filed

17 Catherine Masud and others v Md Kashed Miah and others (2015) 67 DLR 523.

18 Ibid, para 15.

19 Wahid Miah (n 13).

Page $\mid 202$ 
involving tort law claims and very few of them ultimately see some light. My opinion is based on the very few number of reported cases in the law journals involving tort law cases. Here the problem for development of tort law is certainly not legal as our apex court has given the judges the power to create tort law and apply them to any given scenario. Rather the problem is with our reluctant attitude towards developing tort law in this country. The solution, in my opinion, lies with the increase in judicial activism in all the courts of our jurisdiction while dealing with tort law claims. Bearing in mind the extreme effect of tort on the family of the victim and the plaintiff, high time has come to take the matter seriously and work on the substantial development of tort law within our legal system.

In tort law claims, one of the most important issues relates to the identification of the heads of damages and assessing the quantum of damages. In the Bangladesh Beverage Industries Limited case, plaintiffs claimed damages on several heads on the basis of the monthly salary of the deceased till his retirement age, receivable increments per year, potential earning for subscribing articles in different papers and journals, deprivation of the minor sons of their father's affection, care and nursing, jeopardy in the education of the children, loss caused by sudden and untimely widow-ship of the wife of the deceased along with her deprivation from her husband's care, protection, nursing and affection, struggle for food, homestead, treatment and other benefit, other potential income and loss of reputation of the family. Relying on Sri Manamath Nath Kuri v Mvi Md Mokhlesur Rahman and another, ${ }^{20}$ the High Court Division held that the plaintiffs are entitled to compensation for continuous pain and suffering and such compensation must have to be given in a lump sum basis and not on calculation.

In the Bangladesh Beverage Industries Limited case, the Appellate Division drew a distinction between general damages and special damages. General damages flow from the kind of harm and loss which naturally and normally follows from the wrong and which do not need to be specifically pleaded and proved, such as personal injuries, pain and suffering, loss of limbs, loss of expectation of life, future pecuniary loss etc. Special damages flow from such kind of loss as will not be legally presumed to have followed from the defendant's wrongful act, but which must be specifically pleaded and be strictly proved, such as pecuniary loss actually suffered up to the date if trial, e.g. loss of earning etc. So far as the actual or prospective pecuniary loss is concerned the amount of compensation can be assessed with a degree of accuracy. ${ }^{21}$ The principle of fair and reasonable compensation is more appropriate to non-pecuniary heads of damage such as pain and suffering. It has been well established that pain and suffering is a head of damage for which monetary compensation can be awarded. ${ }^{22}$ Moreover, the Appellate Division with approval cited some observations of the case law reported in 22 DLR (SC) 51 which is as follows:

"26. Assessment of damages in such a case must, therefore, necessarily be to some extent of a rough and approximate nature based more or less on guess

20 Sri Manamath Nath Kuri v Mvi Md Mokhlesur Rahman and another (1960) 22 DLR (SC) 51.

21 Bangladesh Beverage Industries Ltd (n 1), para 28.

22 Ibid. 
work, for, it may will be impossible to accurately determine the loss which has been sustained by the death of a husband, wife, parent or child."23

The Appellate Division further held that no definite or hard and fast rule can be laid down respecting assessment of damages in tort law claims. The plaintiff would be able to recover damages for their financial sufferings that they would be able to prove. While making the assessment of such damages, the court will have to take into account the age of the deceased, his or her health, earning capacity and also the chances of advancement. There must be evidence of "reasonable expectation of pecuniary advantage" as opposed to "mere speculative possibility." "4

In the British American Tobacco case, the Appellate Division recognized the devastating effect of sexual harassment on both the economic opportunities and physical and emotional well-being of a working woman. The Appellate Division further noted that sufferings arising out of sexual harassment may include insomnia, depression, nervousness, fear, feeling of powerlessness and other symptoms of psychological harm which sometimes may lead to a complete emotional breakdown. In consequence of this emotional breakdown and sometimes independently physical effects such as headache, loss of appetite, loss of weight, nausea and fatigue may occur. It hinders a woman's chances of economic prospects by reducing her efficiency and productivity at work. Therefore, sexual harassment definitely gives rise to the liability under the law of tort. ${ }^{25}$

In the most recent case of Catherine Masud and Ors. $v$ Md. Kashed Miah and Ors. ${ }^{26}$ the High Court Division while disposing of an application under section 128 of the Motor Vehicles Ordinance, 1983 for compensation over the road accidental death of Abu Tareque Masud and injuries caused to claimant No. 1, Catherine Masud, reviewed the related laws of the country in great details. Here claims were made under different heads, such as loss of income, loss of dependency, loss of future advancement, loss of estate, loss of love and affection, medical expenses, funeral expenses and damages to property.

In the Catherine Masud case, the High Court Division while determining the issue of quantum of compensation rightly observed that neither the Motor Vehicle Ordinance nor the Motor Vehicle Rules nor any other statute prescribes any criteria or guideline in determining the quantum of compensation payable in case of a road accident. ${ }^{27} \mathrm{~A}$ thorough perusal of the judgment in the Catherine Masud case makes it abundantly clear that the High Court Division thoroughly followed the guidelines of the Bangladesh Beverage Industries Limited case, word by word, while determining the quantum of damages in favour of the plaintiffs in that case. The High Court Division further quoted the following guidelines from the Bangladesh Beverage Industries Limited case in this regard:

\footnotetext{
3 Ibid, para 29.

24 Ibid.

25 British American Tobacco Bangladesh Company Ltd. (n 8) para 11.

26 Catherine Masud and Ors. v Md. Kashed Miah and Ors. (2018) 70 DLR 349.

27 Ibid, para 186.
}

Page | 204 
"It is the consistent view of the apex courts of the Sub-Continent and also of the courts of the United Kingdom that assessment of damages in such cases necessarily be to some extent of rough and approximate nature based more or less on guess work because it would be impossible to accurately determine the loss which has been sustained by the death of the victim who happened to be the husband and the father of the plaintiffs. It has also been observed in the decision reported in 22 DLR (SC) 51 at page 59 that although no rule of mathematical calculation can be adopted in every case yet it is the duty of the plaintiff to adduce some evidence to afford the court a reasonable basis for the ascertainment of the damages suffered. The Supreme Court of Pakistan in the decision reported in 22 DLR (SC) 51 held that merely because some element of guess work has been introduced in the calculation it cannot be said that there has been any departure from the principles laid down in the decided cases for determining the quantum of damages in such cases." 28

Therefore, in light of the observations given by both the Divisions of our Supreme Court, it can safely be assumed that neither Division gave any concrete guideline for determining the quantum of damages in a tort law claim. However, at the same time, it should have to be borne in mind that both the Divisions awarded damages and compensation favoring the plaintiffs from where it is easily inferable that the plaintiff succeeded in proving their case and cause of action and won damages of tortious nature. Hence, the issue obviously arises as to the basis on which both the Divisions relied while compensating the plaintiffs with damages of tortious nature because every award of compensation given by the court of law must have to be supported by concrete basis and sound reasoning. If such basis can be discovered in light of specific reference, no doubt the same will enormously assist the lawyers practicing the laws of tort, the judge giving judgment in tort law cases, academicians researching in tort law and lay people thinking of how to agitate their grievances with appropriate evidence before the proper forum.

From judgments of the Bangladesh Beverage Industries Limited case and Catherine Masud case, it is clear that both the Divisions of the Supreme Court have adopted similar views regarding the test to be applied in determining the quantum of damages of tortious nature. Five very important principles become apparently visible from a thorough reading of those judgments. Firstly, ascertainment of damages of tortious nature cannot be based on a mere rule of mathematical calculation. Secondly, such assessment of damages by the court would largely depend on a guess work on the basis of rough and approximate estimate of damages sustained by the plaintiff. Thirdly, the plaintiff requires to prove his or her damages by adducing evidence in support of his or her claim. Fourthly, the evidence adduced by the plaintiff in this connection would be of such nature so as to afford the court a reasonable basis for the ascertainment of the damages suffered. And finally, the whole assessment of quantum of damages by the court would have to be based on an objection basis, and certainly not on a subjective basis.

In the Catherine Masud case, the High Court Division while considering the aspect of damages sustained by the plaintiffs on account of loss of their dependency took into 
account the monthly income of the deceased Tareque Masud which the plaintiffs proved by adducing his income tax returns, the fact that Tareque Masud was a renowned film-maker which was a matter on record and also the fact that there was nothing on the record to show that he had any health problem. The High Court Division then considered the aspect of compensation on account of loss of love and affection. While considering this head, the Division held that this is a very sensitive aspect and there is no concrete and strict principle for quantifying love and affection in terms of money and also that the nature of relationship between the deceased and the plaintiffs was a very important consideration which can be proved by facts showing continuous and visible manifestation of love. The High Court Division considered the aspect of loss of future advancement as being too remote as it gets merged with the of loss of dependency. The High Court Division in considering the head as to loss of estate found no evidence in support of the plaintiff's claim. In considering the head of medical expenses, funeral expenses and the destroyed vehicle, the High Court Division took into account the relevant evidence adduced by the plaintiffs in the concerned behalf. Therefore, the Catherine Masud case makes it clear that the plaintiffs entitlement to damages of tortious nature is a matter of evidence, and also that the principles laid down in the Bangladesh Beverage Industries Limited case are to be strictly adhered to while making an assessment of damages.

From the discussions as made above, it is manifestly clear that the law of tort is a recognized cause of action under the legal system of Bangladesh. Our Appellate Division and the High Court Division have considered various causes of action under the law of tort and have awarded compensation and damages of tortious nature in favor of the plaintiffs. A thorough analysis of the judicial attitude towards development of tort law in Bangladesh demonstrates the emphasis given by our Supreme Court primarily on the recognition of different heads of damages sustained by the plaintiffs in tort law claims. Our Supreme Court has also shown concern regarding the test to be applied while assessing the quantum of damages. However, in my opinion, it is also very important to understand the elements of different torts including negligence because the plaintiffs will need to prove these elements first in the trial court before winning his or her tort law claim. Then shall eventually come the aspect of quantum of damages. As our Appellate Division has expressly stated that the courts are empowered even to create new torts, our trial courts should not be hesitant to develop tort law in line with the settled laws of our country, the UK and other advanced jurisdictions. Undoubtedly the law of tort and tortious liability is already an established feature of our jurisprudence. Certainly, time has come to develop the laws of tortious liability in Bangladesh in a more radical fashion to respond to different social changes and challenges. In the presence of such approval being given by the highest court of our country, all the courts of law should take the matter seriously and should apply their judicial mind to ensure development of tortious liability further within their jurisdiction. 